\title{
Experimental investigations of spray flow rate and angle in enhancing the performance of PV panels by steady and pulsating water spray system
}

\author{
Mojtaba Nateqi ${ }^{1} \cdot$ Mehran Rajabi Zargarabadi $^{2} \cdot{\text { Roohollah } \text { Rafee }^{2}}^{2}$
}

Received: 24 October 2020 / Accepted: 6 January 2021 / Published online: 13 January 2021

(c) The Author(s) 2021 OPEN

\begin{abstract}
In this study, a spray cooling system is experimentally investigated to increase the photovoltaic panel efficiency. Cooling of photovoltaic panels is one of the important parameters that affects the PV panel performance. In this experiment the effects of spray angle, nozzles to PV panel distance, number of nozzles, and pulsating water spray on the PV panel performance are investigated. For this purpose, an experimental setup was made. The spray angles varied from $15^{\circ}$ to $50^{\circ}$. The comparison between the spray angles shows that by decreasing the spray angle to $15^{\circ}$ increases the electrical efficiency of PV panel to $19.78 \%$ and simultaneously the average PV panel temperature decreases from 64 (for noncooled PV) to $24^{\circ} \mathrm{C}$. Also, nozzle to PV panel distance was changed from 10 to $50 \mathrm{~cm}$. The best result was obtained for the lowest distance by $25.86 \%$ increase in power output. Study of various frequency also show that due to the surface evaporation and the intensity of the radiation, increasing the water spraying frequency can increase or decrease the electrical efficiency. The On-Off water spray system results show that the maximum increase in efficiency was obtained with frequency of $0.2 \mathrm{~Hz}$ which it was $16.84 \%$. Water consumption also decreased to half.
\end{abstract}

Keywords Spray cooling · Photovoltaic panel efficiency · Spray angle $\cdot$ Nozzles to PV panel distance $\cdot$ Pulsating water spray

\section{List of symbols}

$A_{m} \quad$ Surface area, $m^{2}$

a Absorptivity coefficient

E Measured solar irradiation, $\mathrm{W} / \mathrm{m}^{2}$

e Evaporation coefficient

g Gravity acceleration, $\mathrm{m} / \mathrm{s}^{2}$

$\mathrm{H} \quad$ Nozzles to PV panel distance, $\mathrm{cm}$

$\mathrm{H}$ Convection heat transfer coefficient, $\mathrm{W} / \mathrm{m}^{2 \mathrm{~K}}$

I Current, $\mathrm{A}$

$\mathrm{I}_{\mathrm{sc}} \quad$ Short circuit current, A

$\mathrm{L} \quad$ Distances between nozzles, $\mathrm{cm}$

$\mathrm{p} \quad$ Partial pressure, $\mathrm{Pa}$

$\mathrm{P}_{e} \quad$ Electric power output of the PV panel, $\mathrm{W}$

$P_{p} \quad$ Power absorbed by the pumping system, $W$

$\mathrm{Q}_{C} \quad$ Convection heat loss, $\mathrm{W}$

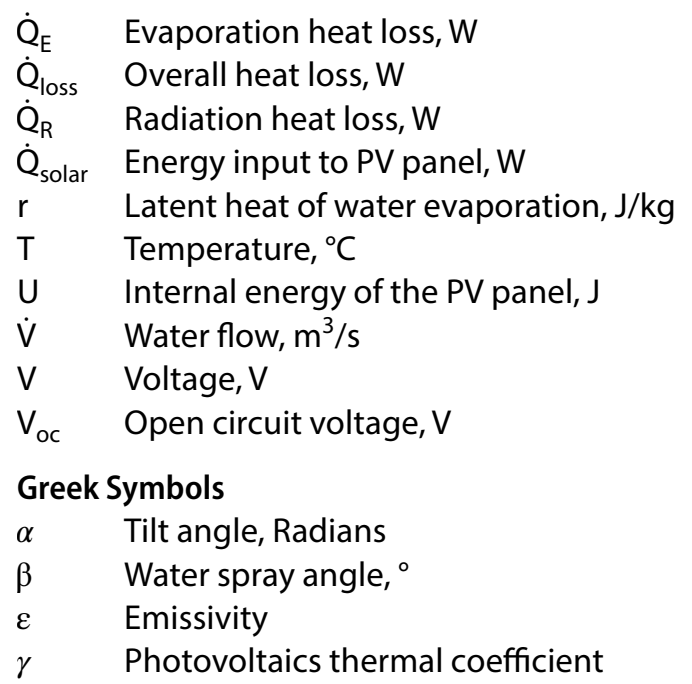

Mojtaba Nateqi, m.nateqi@semnan.ac.ir| ${ }^{1}$ Department of Energy Systems Engineering, Faculty of Mechanical Engineering, Semnan University, Semnan, Iran. ${ }^{2}$ Faculty of Mechanical Engineering, Semnan University, Semnan, Iran. 
$\tau \quad$ Time period, $s$

$\sigma \quad$ Stefan-Boltzmann constant, $\mathrm{W} / \mathrm{m}^{2} \mathrm{~K}^{4}$

$\eta \quad$ Electrical efficiency, \%

$\rho$ Density, $\mathrm{kg} / \mathrm{m}^{3}$

\section{Introduction}

Among renewable energy resources, solar energy is one of the most accessible resources. Hot arid regions have a great potential of solar energy all over the world. Due to solar systems' capability of being operated in different kinds of environmental conditions, many analyses have been done over its behavior in different conditions; results have shown that only $15-20 \%$ of solar irradiation is able to be converted to electricity and the remaining percentage is wasted as heat [1]. As far as the efficiency of photovoltaic solar cells decreases with an increase in temperature [2], cooling them becomes essential to obtain better performance. Earlier theoretical and experimental studies have proven the efficiency decrease which is expected. When the short circuit current $\left(\mathrm{I}_{\mathrm{sc}}\right)$ increases slightly with increasing temperature, in [3] showed that the open circuit voltage $\left(\mathrm{V}_{\mathrm{oc}}\right)$ decreases significantly about $-2.3 \mathrm{mV} /{ }^{\circ} \mathrm{C}$ with increasing temperature. This results in a reduction of electrical power output and electrical yield of $-0.4 \% /{ }^{\circ} \mathrm{C}$ to $0.5 \% /{ }^{\circ} \mathrm{C}$ for mono- and multi crystalline silicon solar cells, respectively. It is common that electrical efficiency in photovoltaic systems can be improved if module temperature is decreased.

To reduce the module temperature, different cooling techniques have been used during recent years. The PV cooling systems are divided to two groups: Active cooling methods and passive cooling technologies. Passive cooling methods do not use any kind of additional power supply to provide cooling but on the other hand active cooling is operated by fans or pumps. It is clear that active technologies are more effective than passive ones. Natural air flow over and under the PV module is one of the simple and cheapest ways for passive cooling which can be enhanced by insertion of colorless and lucid silicon coat [4], micro porous evaporation foils [5], using cotton wick structures in combination with water, $\mathrm{Al}_{2} \mathrm{O}_{3}$ /water nanofluid and CuO/water nanofluid [6], and PCM-Integrated PV modules using nano particles for cooling [7]. Cooling by natural air flow can be done by utilizing air cooled heat sinks [8] or by a ventilated photovoltaic facade [9] due to the average of PV module temperature which is in the range of $50-70^{\circ} \mathrm{C}$ [10]. Hasan et al. [11] achieved a maximum reduction in temperature by $21^{\circ} \mathrm{C}$ by using PCM in several experiments. In general, passive cooling methods mostly achieve range of $6-20{ }^{\circ} \mathrm{C}$ reduction in module temperature and reach the average of $15.5 \%$ in electrical efficiency [12].

Similarly, active cooling technologies have been investigated. Krauter [13] used a water film flow on the front side of the PV module, using several nozzles and a pump to supply the water circuit. The module temperature reached $22{ }^{\circ} \mathrm{C}$ and a net gain in electrical yield of $8-9 \%$ was achieved. A novel active cooling system investigated by Abdolzadeh and Ameri [3] related to a Photovoltaic Pumping System (PVPS) application. PVPS provided part of pumped water to a spraying system to cool the front side of the PV module. The maximum increase in electrical efficiency reached about $17 \%$ during the whole day. In the majority of cooling methods, water has been used as a coolant for front side, backside and in some cases both sides of the PV module. For instance, Alami [14] experimented with the effect of passive evaporative cooling system on PV module performance and achieved a maximum increase of $19.1 \%$ in output power. Water spray cooling on both sides was studied by Nizetic [15] with a maximal total increase of $16.3 \%$ in electric power output. Furthermore, some cooling techniques which include water as their coolant were investigated in [16] and [17], where the range of achieved increase in power output is $10-20 \%$. In addition to the cooling methods above, overall efficiency of PV modules can be enhanced by using hybrid PV-thermal energy systems. Several experimental and numerical studies have been done to improve the PV module performance. [18, 19], and [20].

This paper presents a developed experimental setup to study the effect of water spraying, cooling the front side of the PV panel on PV panel performance. Two parameters, spray angle and nozzles to PV panel distance were varied to obtain the maximal electrical efficiency and output. While many experiments were conducted in recent years, these parameters were neglected [15]. Number of nozzles has been changed to reduce the water consumption during the cooling process. In addition, a solenoid valve was utilized in companion with a super timer (control box) to change the water spray frequencies. In this way the water consumption decreased to half.

The purpose of this study is to increase the electrical efficiency of the photovoltaic system by using the optimal water spray cooling technique. According to the literature review, increasing the efficiency of the photovoltaic system is associated with high water consumption. In this study, a new effort was made to increase the electrical efficiency of the photovoltaic panel while reducing the water consumption. For this purpose, the parameters affecting the water spray cooling system including spray angle, nozzle to PV panel distance, number of nozzles, and frequency of water spray are investigated and the most optimal system has been achieved. In the beginning, the 
experimental setup is introduced. Then, the measurement error analysis has been theoretically explained based on the measurement instruments used in the experiments. At the end of section two, the analytical method is generally defined including the essential equations. Section three indicates the set six different sets of experiments. The discussions and results can be seen in each part. The final section contains the conclusions and also possible future directions for research.

\section{Experimental setup}

\subsection{Experimental setup configuration}

According to Fig. 1, a specific system was set from an 85-W PV monocrystalline module with an effective surface of $0.59 \mathrm{~m}^{2}$. The module's characteristics are available in Table 1. A special structure carries the pipe and its nozzles in a way to avoid shading. Shading is a major problem in PV panels since shading only one cell can significantly drop the output power. According to the PV panel and the setup's position which both are facing south and the setup was located right behind the panel, there is no shading problem during the experiments.

To maximize electricity output and based on the geographical location of the test: the yard of the heat transfer laboratory at Semnan University, Semnan, Iran; the module was fixed under an angle of $30^{\circ}$ with south orientation. The current and the voltage of the system were being tracked by two multimeters, Excel 9205 a, with a rheostat resistor, ES100W. Rheostat resistance was set to different
Table 1 General characteristics of the tested PV module at standard test conditions $\left(1000 \mathrm{~W} / \mathrm{m}^{2}\right.$ and $\left.25^{\circ} \mathrm{C}\right)$

Technical characteristics

\begin{tabular}{ll}
\hline Model & STP085-12/BEA \\
\hline Maximum power output & $85 \mathrm{~W} \pm 5 \%$ \\
Number of cells & 36 \\
Maximum current/short circuit current & $4.8 \mathrm{~A} / 5.15 \mathrm{~A}$ \\
Maximum voltage/open circuit voltage & $17.8 \mathrm{~V} / 22.2 \mathrm{~V}$ \\
Module effective area & $0.59 \mathrm{~m}^{2}$ \\
Power temperature coefficient & $-0.46 \% /{ }^{\circ} \mathrm{C}$ \\
\hline
\end{tabular}

values ranging from 0 to 100 ohms to reach the maximum power point (MPP) of the PV panel.

A pyranometer, SPM-1116SD, was used to measure solar irradiation during the experiments. The system was also equipped with measuring devices for PV panel temperature by MIT-367 infrared thermometer with accuracy of $\pm 2{ }^{\circ} \mathrm{C}$, environmental temperature by a digital thermometer TPM 10F, and, also a water mass flow meter. A $140-\mathrm{cm}$ pipe carrying nine nozzles was provided with an average water pressure of 4.8 bars due to the city water system.

Figures 2 and 3 demonstrate the cooling structure of the current experiment which provided different angles of spray by using locking clamps. Another specific feature was the ability to set the system on five different distances from the PV panel surface. The distance between the panel upper edge and the set of nozzles was adjustable from 10 to $50 \mathrm{~cm}$ in 5 different modes $(10,20,30,40$ and $50 \mathrm{~cm})$. Water went through an iron pipe with nominal diameter of $1 / 2$ inch equals $1.5 \mathrm{~cm}$.

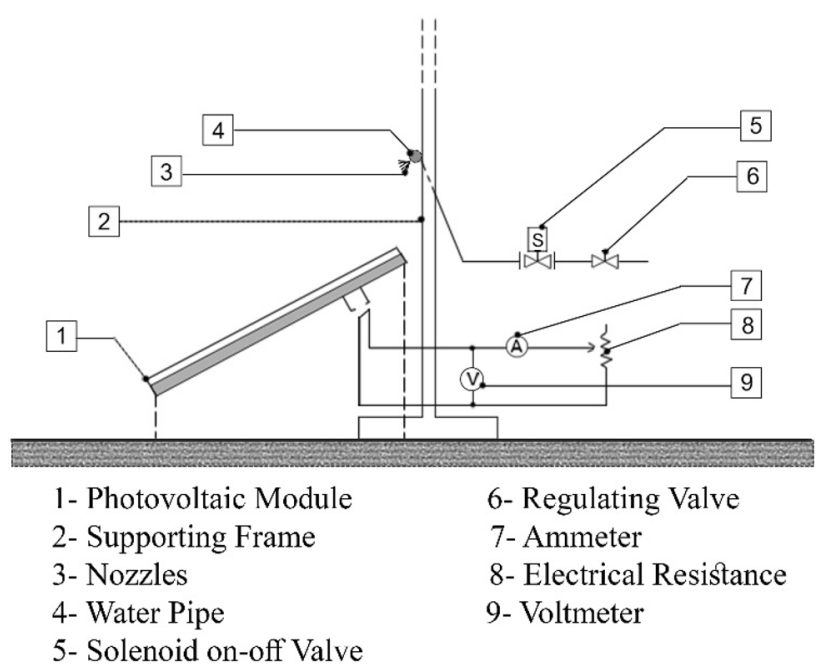

Fig. 2 Schematic layout of the experimental setup

Fig. 1 General layout of the experimental setup 


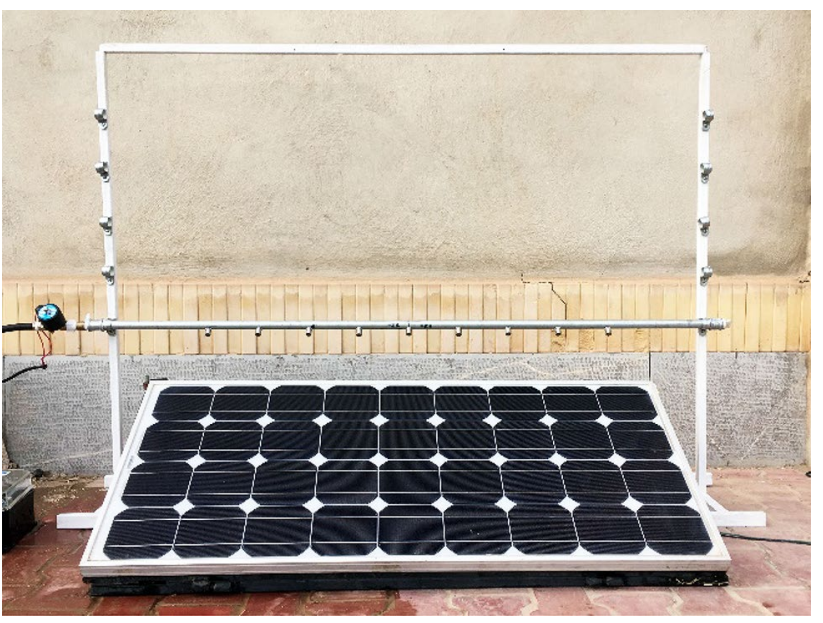

Fig. 3 PV module under the water spray cooling with its specific experimental setup

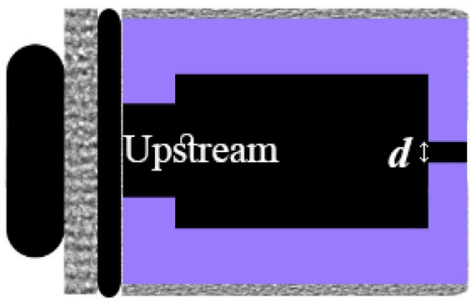

(a)

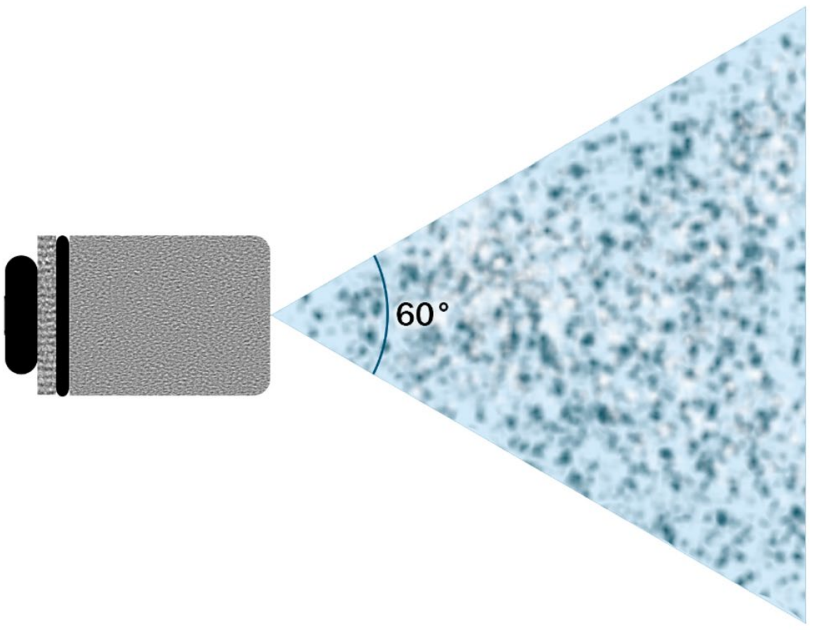

(b)

Fig. 4 a Plain-orifice main geometry and $\mathbf{b}$ the spray nozzle fog pattern

The nozzles' placement and their distance were considered to spray on each cell of the module ( 9 nozzles on the top of 9 cells). The distances between the nozzles were $12 \mathrm{~cm}$. Low pressure plain orifice $25 \mathrm{M}$ spray nozzles were used. As the plain-orifice main geometry of nozzles can

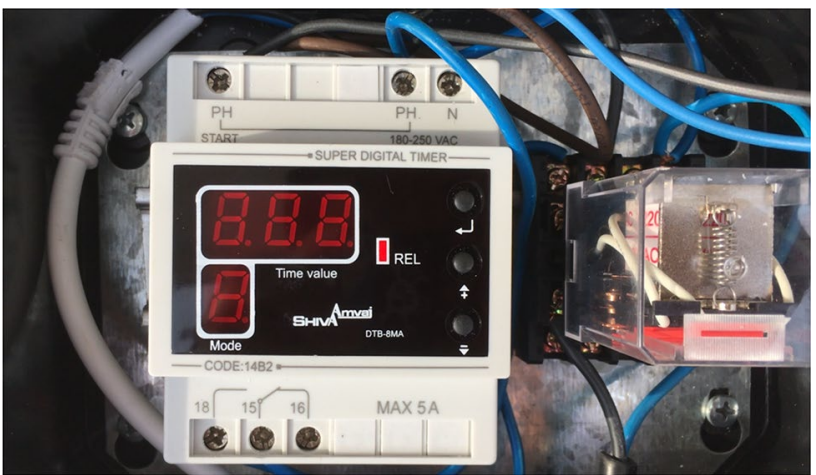

(a)
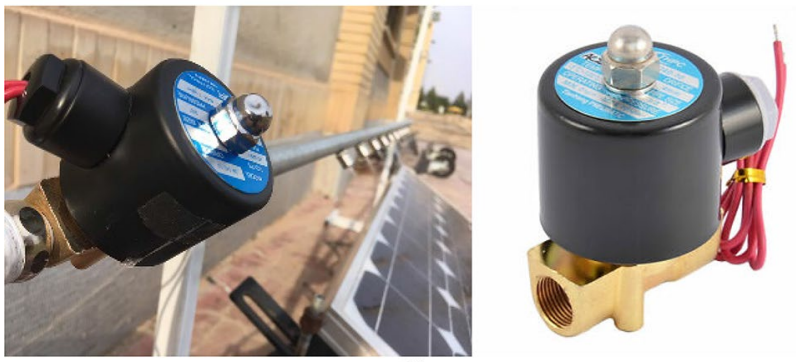

(b)

Fig. 5 a The timer and $\mathbf{b}$ On-off solenoid valve

Table 2 Measurement error for the used measuring equipment

\begin{tabular}{ll}
\hline Measuring Equipment & $\begin{array}{l}\text { Measure- } \\
\text { ment Error } \\
(\%)\end{array}$ \\
\hline Amperemeter & \pm 2 \\
Pyranometer & \pm 5 \\
Voltmeter & \pm 0.5 \\
\hline
\end{tabular}

be seen in Fig. 4. (a), $\boldsymbol{d}$ is the main diameter which is 5 microns. Every single nozzle provides $60^{\circ}$ spray angle and $9 \mathrm{l} / \mathrm{h}$ flow rate as shown in Fig. $4 \mathrm{~b}$.

The final tests were done by using a solenoid valve and a timer to provide a pulsating water spray in order to reduce water consumption. Three different on-off time periods were tested to find the optimal time for cooling the PV panel surface. Figure 5 demonstrates the super timer and on-off solenoid valve.

\subsection{Measurement error analysis}

In this part, expected measurement error is discussed for the measuring equipment. The measurement error of each equipment is shown in Table. 2 .

According to Table. 2, the voltmeter error is $\pm 0.5 \%$ and does not significantly affect the measurements. The amperemeter has $a \pm 2 \%$ error which is a significant 
uncertainty. In the case of solar irradiation, the pyranometer error is in the amount of $\pm 5 \%$. According to the electrical efficiency $(\eta)$ formula as Eq. 1, the exact formula for Propagation of Error [21] is used to calculate the electrical efficiency measurement error of $\pm 5.41 \%$ through Eqs. (2) to (8): [22]

$\eta=\frac{P_{\max }}{A \cdot E}=\frac{V \cdot I}{A \cdot E}$

where $V$ is the maximum measured voltage, $I$ is the maximum measured current, $E$ is the solar irradiation measured by the pyranometer, $s$ is the variance, and $A$ is the module effective area which is a constant amount [21].

$\mathrm{s}_{\eta}^{2}=\left(\frac{\delta \eta}{\delta \mathrm{V}}\right)^{2} \mathrm{~s}_{\mathrm{V}}^{2}+\left(\frac{\delta \eta}{\delta \mathrm{l}}\right)^{2} \mathrm{~s}_{1}^{2}+\left(\frac{\delta \eta}{\delta \mathrm{E}}\right)^{2} \mathrm{~s}_{\mathrm{E}}^{2}$

Taking the partial derivative of each experimental variable, $\mathrm{V}, \mathrm{I}$, and $\mathrm{E}$ :

$\left(\frac{\delta \eta}{\delta \mathrm{V}}\right)=\frac{\mathrm{I}}{\mathrm{E}}$

$\left(\frac{\delta \eta}{\delta 1}\right)=\frac{\mathrm{V}}{\mathrm{E}}$

and

$\left(\frac{\delta \eta}{\delta \mathrm{E}}\right)=-\frac{\mathrm{VI}}{\mathrm{E}^{2}}$

Plugging these partial derivatives into Eq. 2 gives:

$s_{\eta}^{2}=\left(\frac{I}{E}\right)^{2} s_{V}^{2}+\left(\frac{V}{E}\right)^{2} s_{1}^{2}+\left(-\frac{V I}{E^{2}}\right)^{2} s_{E}^{2}$

Dividing Eq. 6 by Eq. 1 squared yields:

$\frac{s_{\eta}^{2}}{\eta^{2}}=\frac{\left(\frac{I}{E}\right)^{2} s_{V}^{2}}{\left(\frac{V I}{E}\right)^{2}}+\frac{\left(\frac{V}{E}\right)^{2} s_{I}^{2}}{\left(\frac{V I}{E}\right)^{2}}+\frac{\left(-\frac{V I}{E^{2}}\right)^{2} s_{E}^{2}}{\left(\frac{V I}{E}\right)^{2}}$

Canceling out terms and square-rooting both sides yields the equation below:

$\frac{s_{\eta}}{\eta}=\sqrt{\left(\frac{s_{V}}{V}\right)^{2}+\left(\frac{s_{I}}{I}\right)^{2}+\left(\frac{s_{E}}{E}\right)^{2}}$

\subsection{The applied water spray cooling technique and analytical model}

Following different types of cooling systems for PV modules, water spray cooling is more efficient. Beside the suitable heat transfer done by water spray cooling, its cleaning effect is also fundamental to remove the dust accumulation in some solar power plants. Thus, the main purpose of spray cooling on all parts of the PV module is to maximize heat release to the environment and to minimize the surface temperature to increase electric power output. If we consider $E_{\text {solar }}$ as the incoming solar irradiance into the surface area $A_{m}$, the energy input into the surface is: [22],

$\mathrm{Q}_{\text {solar }}=\mathrm{aE}_{\text {solar }} \mathrm{A}_{\mathrm{m}}$

where a shows the absorptivity coefficient.

Following the solar PV systems characteristics, the major part of the input irradiance is wasted to increase the PV module internal energy $\Delta \mathrm{U}_{\text {module }}$ and the overall heat losses to the environment. Overall heat loss $\left(\dot{Q}_{\text {loss }}\right)$ in this experiment contains three kinds of loss: Convection $\left(\dot{Q}_{C}\right)$, radiation $\left(\dot{Q}_{R}\right)$, and evaporation heat loss $\left(\dot{Q}_{E}\right)$.

Overall PV module heat loss is able to be calculated as Eq. 10, which contains the three kinds of loss as mentioned above:

$\dot{\mathrm{Q}}_{\text {loss }}=\dot{\mathrm{Q}}_{\mathrm{c}}+\dot{\mathrm{Q}}_{\mathrm{R}}+\dot{\mathrm{Q}}_{\mathrm{E}}$

Convection heat loss for PV module can be calculated as follows,

$\dot{\mathrm{Q}}_{\mathrm{c}}=\dot{\mathrm{Q}}_{\mathrm{C}, \mathrm{F}}+\dot{\mathrm{Q}}_{\mathrm{C}, \mathrm{B}}$

where,

$\dot{\mathrm{Q}}_{\mathrm{C}, \mathrm{F}}=\mathrm{h}_{\text {front }} \mathrm{A}_{\mathrm{m}}\left(\mathrm{T}_{\text {module_front }}-\mathrm{T}_{\text {air_front }}\right)$ and,

$\dot{\mathrm{Q}}_{C, B}=\mathrm{h}_{\text {back }} \mathrm{A}_{\mathrm{m}}\left(\mathrm{T}_{\text {module_back }}-\mathrm{T}_{\text {air_back }}\right)$

Total radiation heat loss can be presented as Eq. 14,

$\dot{\mathrm{Q}}_{\mathrm{R}}=\dot{\mathrm{Q}}_{\mathrm{R}, \mathrm{F}}+\dot{\mathrm{Q}}_{\mathrm{R}, \mathrm{B}}$

where radiation heat loss can be calculated as follows,

$\dot{\mathrm{Q}}_{\mathrm{R}}=\sigma \cdot \varepsilon \cdot \mathrm{A}_{\mathrm{m}} \cdot \mathrm{F}_{\mathrm{xy}}\left(\mathrm{T}_{\mathrm{x}}^{4}-\mathrm{T}_{\mathrm{y}}^{4}\right)$

Equation 15 can be calculated for both sides of the module.

Total evaporation heat loss depends on various parameters such as temperature of water spray flow (in the boundary layer of the PV module) and also surrounding air temperature, relative humidity and air velocities.

$\dot{\mathrm{Q}}_{\mathrm{E}}=\mathrm{e} \cdot \mathrm{A}_{\mathrm{m}} \cdot\left(\mathrm{p}_{\mathrm{s}}-\mathrm{p}_{\mathrm{d}}\right) \cdot \mathrm{r}$

where evaporation factor is $\mathrm{e}$, partial pressures are $\mathrm{p}_{\mathrm{s}}$ and $p_{d}$ and $r$ is latent heat of evaporation. The most influential parameter on evaporation heat loss is the evaporation 
coefficient. According to the cooling heat rate from the PV module surface which is exposed to the water spray flow, the average module temperature, the average air velocity, surrounding area temperature and humidity are also important. The heat rejection by evaporation heat flux depends on e (evaporation coefficient), which depends on the surrounding areas' air condition and also the temperature of the thin water boundary layer. Water spray can have negative effect on PV module performance due to light reflection in direct contact with water drops. This negative effect is negligible compared to the positive effect of cooling on PV module performance.

Finally, according to the first law of thermodynamics, PV module temperature can be determined by writing a balance equation,

$\frac{d U \bmod u l e}{d \tau}=\dot{Q}_{\text {solar }}-\dot{Q}_{\text {loss }}-P_{\mathrm{e}}$

\subsection{Energy performance evaluations}

As aim of cooling system is to enhance the energy production. This means that the additional energy produced by cooling system must be more than the energy absorbed for running the cooling system. Although the public water system is used in this research but the power absorbed by the pumping system is calculated as follows [23]:

$P_{p}=\frac{\dot{V} g K}{\eta}$

where $\dot{V}$ is the water flow, $\mathrm{K}$ is prevalence required, $\mathrm{g}$ is gravity acceleration, and $\eta$ is the electrical efficiency.

The time-averaged PV panel's surface temperature value over a time interval $D$ is very important for the system efficiency calculation, and is defined as:

$\mathrm{T}_{\mathrm{avg}}=\frac{1}{\mathrm{D}} \int_{0}^{\mathrm{D}} \mathrm{T}(\mathrm{t}) \mathrm{dt}$

The integration time can be equal to one or more cooling cycles duration. The numeric simulation does not provide a continuous $T_{\text {avg }}$ time function, but a series of points, so the calculation of the integral above must be discretized: the concept is however the same. A cooling duration parameter $\mathrm{D}_{\%}$ is defined as following [23]:

$\mathrm{D} \%=\frac{\mathrm{T}_{\text {on }}}{\mathrm{T}_{\text {on }}+\mathrm{T}_{\text {off }}}$

The energy consumption in duration of a total time $t$ is:

$E_{p}=P_{p} t D \%$
You can find the energy absorbed in an hour of operation $[\mathrm{kWh}]$ as below:

$\mathrm{E}_{\mathrm{ph}}=0.001 \mathrm{P}_{\mathrm{p}} \mathrm{D} \%$

The additional energy production $(\Delta \mathrm{P})$ is related to the temperature decrease obtained by cooling:

$\Delta \eta=\Delta \mathrm{T} \alpha \gamma_{\mathrm{ref}}$

$\Delta \mathrm{P}=\Delta \eta E_{\text {solar }} \mathrm{A}_{\mathrm{m}}$

$\Delta \mathrm{E}_{\mathrm{h}}=0.001 \Delta P$

where. $\gamma_{\text {ref }}$. is the PV module thermal coefficient as given in Table 1 equal to 0.0046 and $\alpha$ is the tilt angle between the ground and the PV module. Energy balance is defined as below, where $E_{g h}$ quantifies the net additional energy produced in one hour:

$E_{g h}=\Delta E_{h}-E_{p h}$

The simulations in different cases have indicated that the overall energy balance is significantly dependent on the atmospheric conditions, the pump prevalence required, and the duration of cooling modes [23].

\subsection{Main objectives}

In this research numerical study of water spray impact on PV module performance is left for further work. The main aim of this research is to investigate the spray angle effect and the distance of nozzles from the PV module. The final goal is to express experimental aspect of water spray cooling impact on PV module power output and electrical efficiency. Also, the water consumption is considered to optimize this method by reducing the number of nozzles from 9 to 5 and 3 nozzles. Furthermore, pulsating water spray has been utilized with 3 different frequencies to reduce water consumption.

\section{Results and discussion}

\subsection{General circumstances}

The spray cooling test was implemented in July in Semnan, Iran (at Semnan University). During the tests, the temperature of surrounding area was in the range of $32^{\circ} \mathrm{C}$ to $37^{\circ} \mathrm{C}$. To get the best and the highest irradiation, all the experiments were performed between 11 and 15, Semnan time. Figure 6 shows the intensity of solar irradiation measured by the pyranometer during one of the experiment days in July. According to the series of measured 


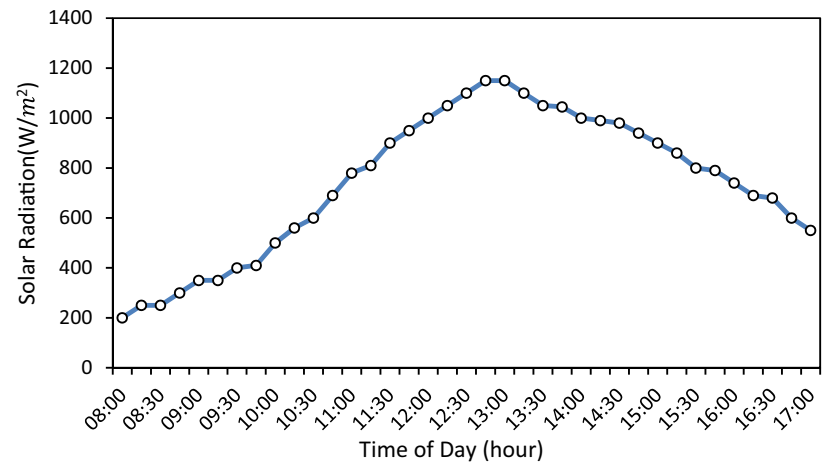

Fig. 6 Solar irradiation intensity (POA) in different hours of 1 day in July in Semnan City

irradiations during the experiments, they ranged from 960 to $1100 . \mathrm{W} / \mathrm{m}^{2}$. which is the highest measured irradiation (POA). According to Iran Solar Atlas, 6.26 to $7.15 \mathrm{kWh} / \mathrm{m}^{2}$ is the daily average irradiation during a day in July in Semnan city.

The average temperature of exit $\mathrm{kWh} / \mathrm{m}^{2}$ water from nozzles is $16.5^{\circ} \mathrm{C}$. In this experiment, due to slow wind (with the speed of less than $1.0 \mathrm{~m} / \mathrm{s}$ ), the effect of wind speed is negligible. Some experiments were done to reach an optimal temporal sequence for water spray cooling and non-cooling modes. The temperature of front PV panel surface was measured for each 2 min, after 10 min of water spraying, the temperature went steady then. After having turned off cooling, it took 20 min to return to its steady temperature in non-cooling mode based on the experiments. Therefore, the PV panel surface temperature was measured in both cooling and non-cooling modes for 10 and 20 min respectively as illustrated in Fig. 7.

\subsection{The effect of water spray cooling system on temperature of $\mathrm{PV}$ panel}

Due to evaporation contribution and the cooling effect of water spraying, the operating PV panel temperature was decreased. The environmental and water temperature were $32{ }^{\circ} \mathrm{C}$ to $37^{\circ} \mathrm{C}$ and $16.5^{\circ} \mathrm{C}$ respectively.

As shown in Figs. 8 and 9 the maximum PV panel temperature occurs for the non-cooled PV panel and its temperature is $64{ }^{\circ} \mathrm{C}$ (average of measured surface temperature) measured by an infrared thermometer right before and after the cooling. Different parts of the front surface of PV panel were measured but the average amount used in the figs below. A $40^{\circ} \mathrm{C}$ decrease occurred with cooling. The minimum cooled PV panel temperature was $24^{\circ} \mathrm{C}$. The minimum PV panel temperatures were observed for

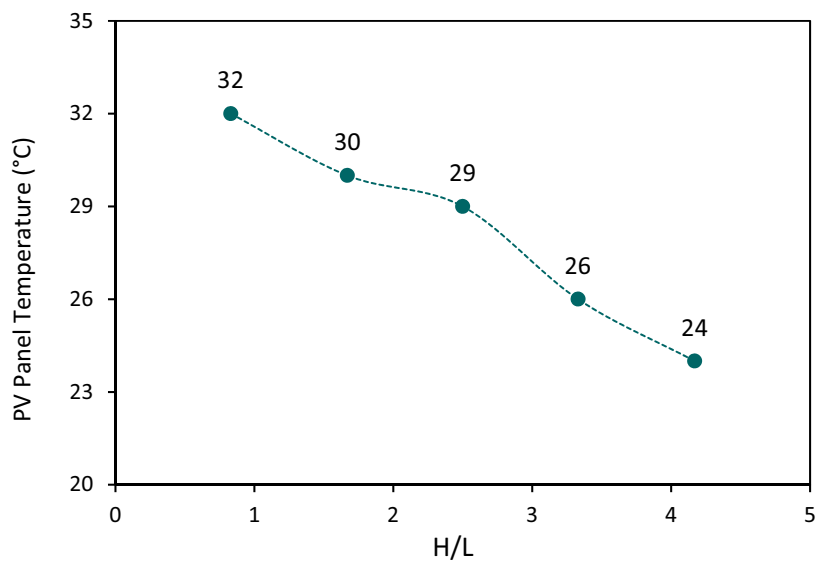

Fig. 8 PV panel surface temperature versus $\mathrm{H} / \mathrm{L}$ with cooling
Fig. 7 Experimental measurements of the PV panel temperature versus time in July

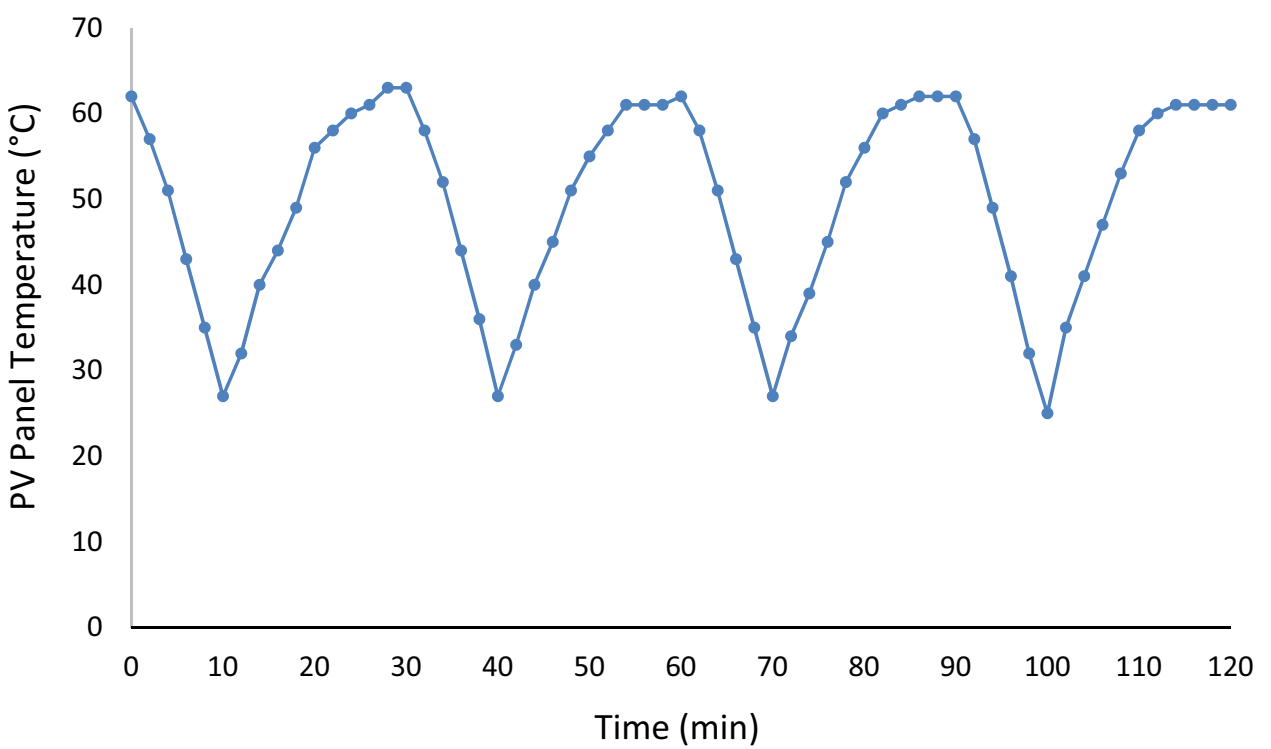

SN Applied Sciences 


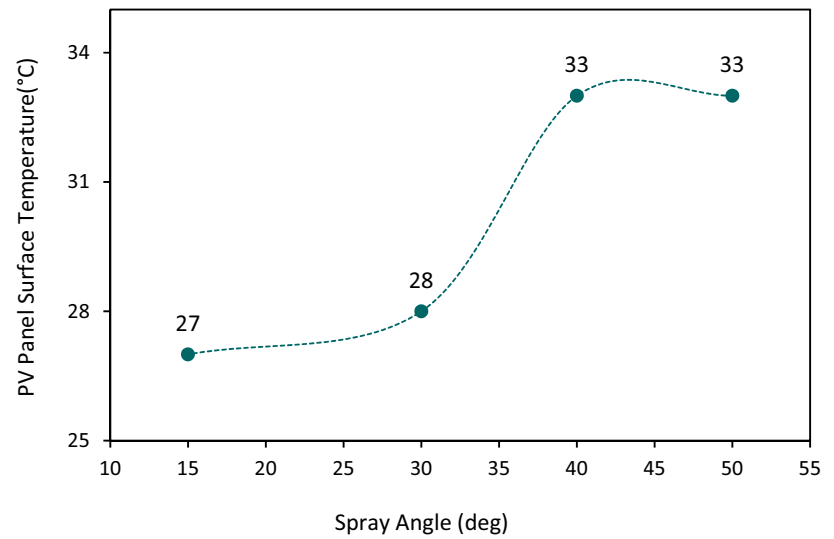

Fig. 9 PV panel surface temperature for different spray angles with cooling

the lowest nozzles to PV panel distance and the smallest angle $15^{\circ}$.

\subsection{The effect of nozzles to PV panel distance on electrical efficiency and power output}

One of the factors affecting the efficiency of the photovoltaic panel is the nozzles to PV panel distance. As it is illustrated in Fig. 10, nozzles to PV panel distance $(\mathrm{H})$ was changed in 5 different modes between 10 and $50 \mathrm{~cm}$. In Fig. 11, the results were compared by a dimensionless number, $\mathrm{H} / \mathrm{L}$.

As shown in Fig. 11, by increasing $\mathrm{H} / \mathrm{L}$ from 0.83 to 4.17 total electrical efficiency decreased from 12.83 to $11.34 \%$. The maximum electrical efficiency occurred at the lowest nozzles to panel distance. The maximal increase in output power was $14.93 \mathrm{~W}$ for $\mathrm{H} / \mathrm{L}$ of 0.83 . While the highest increase in electrical efficiency was $25.86 \%$ which it was the highest amount in all tests in this paper gained in $\mathrm{H} / \mathrm{L}$ of 0.83 comparing non-cooled system. This percentage is the highest amount of increase in comparison with other sets of tests.

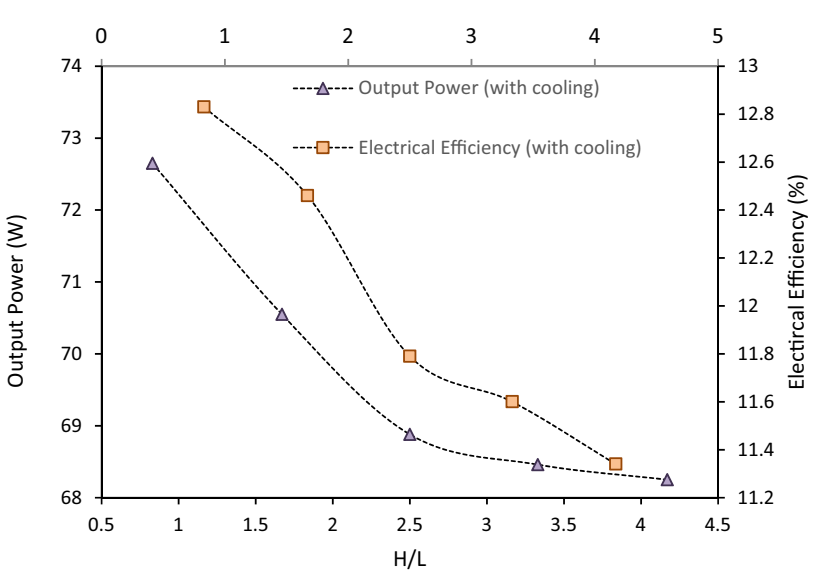

Fig. 11 The effect of nozzles to panel distance on power output and electrical efficiency

The lowest increase in electrical efficiency was obtained for the highest distance from the PV panel $(50 \mathrm{~cm}$ or $\mathrm{H} / \mathrm{L}=4.17$ ).

Nianyong et al. [24] investigated the height effect on cooling of a hot metal surface by water spray cooling in different heights ranging from 0.8 to $5.8 \mathrm{~cm}$. They concluded that by increasing the height by $4 \mathrm{~cm}$, from 0.8 to $4.8 \mathrm{~cm}$, the temperature increased from 55 to $105^{\circ} \mathrm{C}$. In the current research the height effect has been studied using a dimensionless number, $\mathrm{H} / \mathrm{L}$ in the range of 0.83 to 4.17 (it means from 10 to $50 \mathrm{~cm}$ high from the PV panel surface). Likewise, increasing the height caused an increase in PV panel surface temperature.

\subsection{Effects of spray angle on the electrical efficiency and power output of the PV panel}

As in previous experiments, the tests were done in the nearly same climate and irradiation condition between 11 and 15, Semnan time. Following the results shown in Fig. 11, the $10-\mathrm{cm}$ distance is selected for this part. The
Fig. 10 a Cross-section: The nozzles to PV panel distance $(\mathrm{H})$ and $\mathbf{b}$ the distance between each nozzle (L)

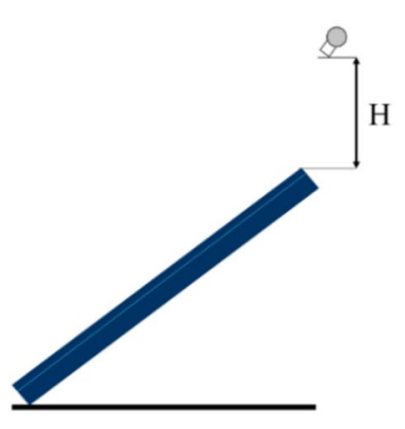

(a)
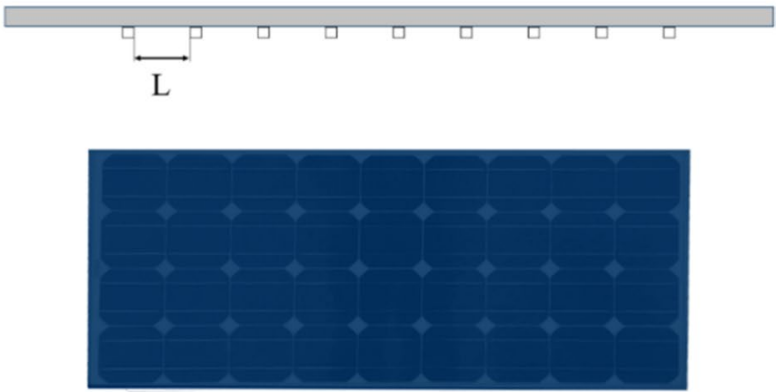

(b) 


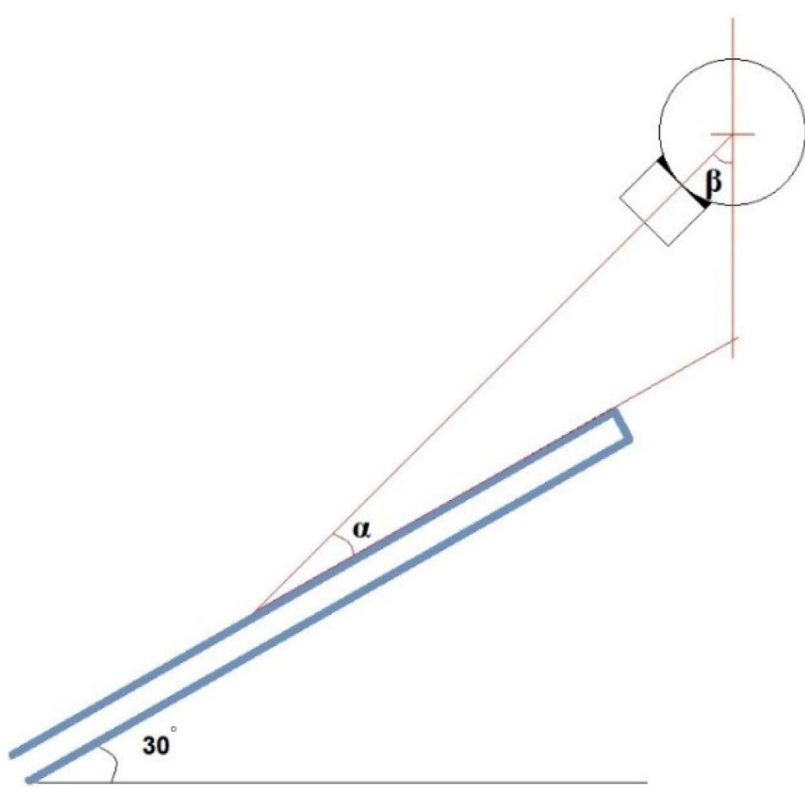

Fig. 12 Cross-section showing the spray angle $\boldsymbol{\beta}$

average irradiation in these sets of tests to examine angle effect was 1100 .

The PV module's tilt angle was again $30^{\circ}$ and four different spray angles ( $\beta$ is shown in Fig. 12 ) between $15^{\circ}$ and $50^{\circ}$ were selecte $\mathrm{W} / \mathrm{m}^{2} \mathrm{~d}$.

Four angles were tested in four different experiments in the same conditions. The maximum output power and electrical efficiency were $78.09 \mathrm{~W}$ and $12.03 \%$ respectively after the cooling with $15^{\circ}$ angle. In $15^{\circ}$ angle, a $19.79-\%$ increase was seen in electrical efficiency. By changing the angle to $30^{\circ}$, electrical efficiency reached $11.89 \%$ (17.64\% increase comparing to non-cooled mode). The overall increase in electrical efficiency after cooling the PV panel with $40^{\circ}$ was $13.95 \%$. The 50 -degree angle of cooling nozzles had the lowest increase in overall output power and electrical efficiency after cooling in comparison with other three angles as shown in Fig. 13.

To validate the experimental data, a similar study is considered. The influence of the effect of angle on spray cooling of hot steel surfaces has been researched by Hnízdil et al. in [25]. They studied the effect of angle on spray cooling nozzles over a hot metal surface. They investigated three angles $\left(20^{\circ}, 30^{\circ}\right.$ and $\left.40^{\circ}\right)$. The nozzles to the surface distance of water spraying in both experiments were $10 \mathrm{~cm}$ and the water pressure was about 4 bars. Their results show that an angle of 20 degrees had the highest heat transfer flux and according to the results and the Leidenfrost effect theory at the same time, smaller angle caused more efficient cooling. Leidenfrost effect is a physical phenomenon in which water or any other liquid, close to a hot surface that is clearly hotter than the liquid's

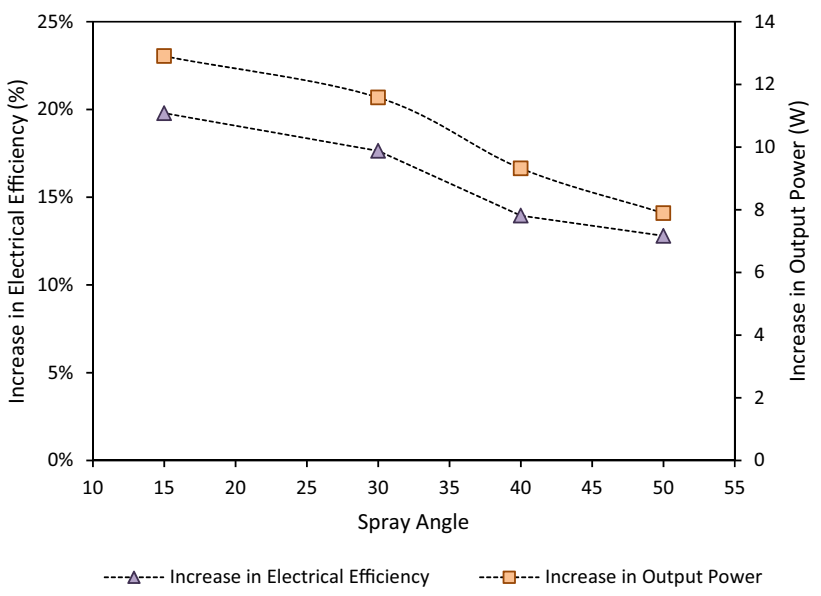

Fig. 13 Increase in electrical efficiency and output power caused by cooling in different spray angle

boiling point, produces an insulating layer of vapor that keeps the liquid from boiling fast. Because of this effect, water droplets move on the surface smoothly and without making physical contact with the hot surface. In this research, the drops move in a rolling motion downward the panel like one would expect in a Leidenfrost condition, even though it does not apply here due to lower temperatures.

This leads to the question: What is the contact angle of the tap water on the panel?

One also could rather expect some electric charge of the droplets in accordance with the panel charge. That may keep the drops from spreading on the surface and may cause a similar movement as due to the Leidenfrost effect. In this paper, four different angles were investigated as presented in Fig. 12 as $\beta=15^{\circ}, 30^{\circ}, 40^{\circ}$, and $50^{\circ}$. Consistent with [25], the highest heat transfer occurred for the smallest angle which is $15^{\circ}$ in this study. More acute angle can provide more water on PV panel surface and less water will be vaporized by angle 15 . Actually, making the angle smaller, a thin layer of water is appeared to supply efficient cooling on PV panel surface.

\subsection{The effect of water spray cooling system on the electrical efficiency and electrical power output of the PV panel}

In this section the effect of the cooling system on the output power and electrical efficiency of the panel is investigated and the results of the cooling system with 9 nozzles simultaneously, nozzle to PV panel distance of $10 \mathrm{~cm}$, water spray angle of $15^{\circ}$ and steady-flow spraying are compared with a PV panel without a cooling system. The experimental results show that the maximum electric power output for non-cooled panel is $65.5 \mathrm{~W}$ while 


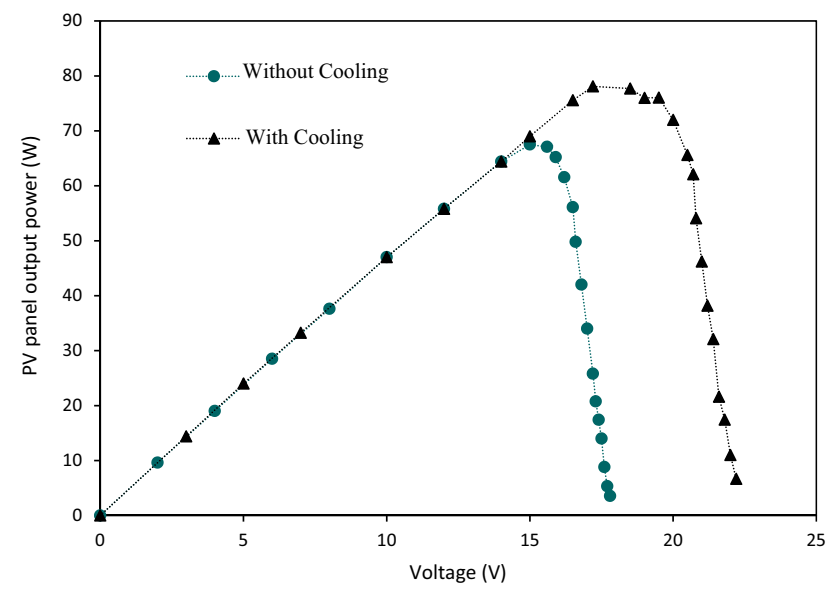

Fig. 14 PV panel output power versus voltage in cooling and without cooling modes

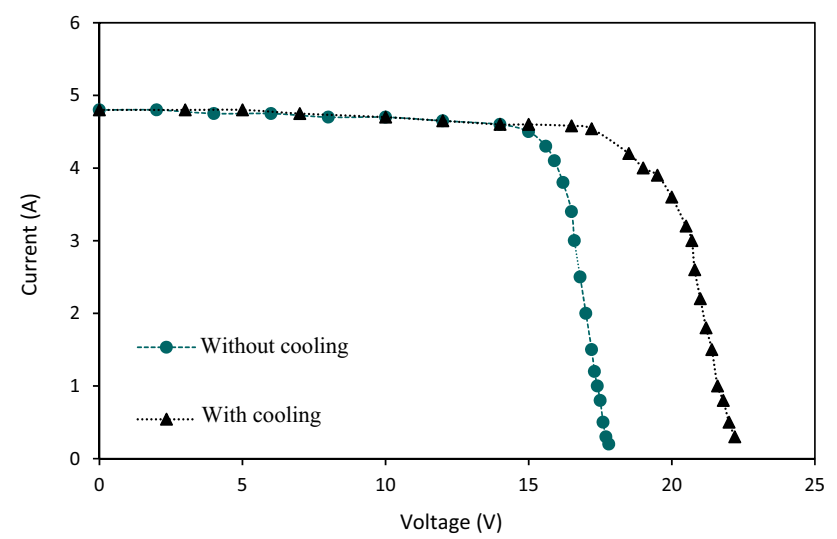

Fig. 15 I-V characteristic curves for the PV panel in cooling and without cooling modes

the maximum measured output power for cooled panel is $78.1 \mathrm{~W}$ as shown in Fig. 14. The maximum increase in output power of PV panel was $12.6 \mathrm{~W}$ in comparison with non-cooled panel. The measured voltage in maximum power point of the non-cooled was $15.9 \mathrm{~V}$ and reached 17.2 $\mathrm{V}$ after the cooling. I-V characteristics are presented in Fig. 15. The average maximum electrical efficiency for the cooled and non-cooled PV panel were 12\% and 9\% respectively. Thus, the electrical efficiency of $\mathrm{PV}$ panel with cooling system increased $19.8 \%$ comparing non-cooled system. The measurements of this set of tests show that the average temperature of the PV panel decreases $30^{\circ} \mathrm{C}$ by using the cooling system in comparison with noncooled PV panel.

Water spray cooling technique was applied on a PV module by Nizetic et al. [15] using 10 nozzles on the front and 10 on the back side of the PV module. A comparison can be made between our experiments and Nizetic et al.'s front side cooling results [15] as presented in Table 3.

The comparison between the experimental data of Nizetic et al. [15] and the present study shows that in this study, by using less nozzles and the choice of optimum spray angle and distance to PV nozzles, the efficiency of the PV panel is increased $9.02 \%$ more than Nizetic et al. [15].

\subsection{The effect of different number of nozzles on electrical efficiency and power output of PV panel}

Although the water flow rate in this research which was about $81 \mathrm{l} / \mathrm{h}$, is lower than other similar spray cooling methods in [15] and [3], decreasing the number of nozzles can be also useful to reduce the water consumption and reduce the total water flow rate. As water flow rate is one of the effective parameters in heat transfer, adding or reducing the number of nozzles influences the heat transfer coefficient and reduce or increase the heat transfer rate. In this study some of the nozzles were removed to reduce water consumption.

Water spray cooling was studied in three modes of 9,5 and 3-nozzle. The total flow rates in these modes were: 81 , 45 and $21 \mathrm{l} / \mathrm{h}$ as illustrated in Fig. 16. The flow rate in different number of nozzles is not proportional due to pressure drop at each nozzle.

While the number of nozzles is 9 the electrical efficiency and output power increased $19.08 \%$ and $12.27 \mathrm{~W}$ respectively compared to non-cooling mode. Also, the increase in electrical efficiency for 5 and 3 nozzles were $11.59 \%$ and

Table 3 Comparison between the experimental data of Nizetic et al. [15] and the present work

\begin{tabular}{|c|c|c|c|c|c|c|}
\hline Cooling options & $\begin{array}{l}\text { Relative increase } \\
\text { in power output } \\
\text { (Nizetic et al. [15]) } \\
\text { (\%) }\end{array}$ & $\begin{array}{l}\text { Relative increase } \\
\text { in power output } \\
\text { (Present work) } \\
\text { (\%) }\end{array}$ & $\begin{array}{l}\text { Relative increase } \\
\text { in electrical } \\
\text { efficiency (Nizetic } \\
\text { et al. [15]) } \\
(\%)\end{array}$ & $\begin{array}{l}\text { Relative increase } \\
\text { in electrical } \\
\text { efficiency (Present } \\
\text { work) } \\
(\%)\end{array}$ & $\begin{array}{l}\text { Average PV panel } \\
\text { surfaces tempera- } \\
\text { ture (Nizetic et al. } \\
[15]) \\
\left({ }^{\circ} \mathrm{C}\right)\end{array}$ & $\begin{array}{l}\text { Average PV panel } \\
\text { surfaces tempera- } \\
\text { ture (Present work) } \\
\left({ }^{\circ} \mathrm{C}\right)\end{array}$ \\
\hline Without cooling & - & - & - & - & 56 & 64 \\
\hline $\begin{array}{l}\text { Front surface } \\
\text { cooling }\end{array}$ & 14.6 & 16.03 & 10.78 & 19.8 & 29.6 & 34 \\
\hline
\end{tabular}




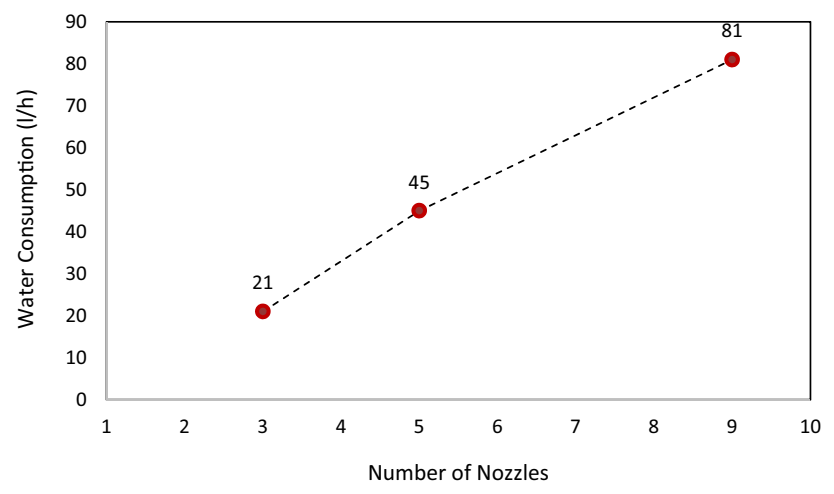

Fig. 16 Water consumption for different number of nozzles

8.73\% respectively comparing to non-cooled PV panel. According to the results, total flow rate of nozzles, number of nozzles and the PV panel performance have a direct correlation with each other as shown in Fig. 17.

\subsection{Pulsating water spray effect on PV panel performance}

In this study, a new effort was made to reduce the cooling water consumption of the photovoltaic system. Therefore, a system is used to turn the water spray flow on and off. Different frequencies were tested to investigate the on-off spray cooling effect on PV panel performance. For this purpose, 3 modes were studied to get the highest increase in electrical efficiency and output power. Each test was done in two conditions to compare steady and pulsating water spray. $0.1 \mathrm{~Hz}$ (10 s On-10 s Off), $0.2 \mathrm{~Hz}$ (5 s On-5 s Off) and $0.33 \mathrm{~Hz}$ (3 s On-3 s Off) were compared with steady water spraying on the same day. Since frequency of $0.33 \mathrm{~Hz}$ doesn't let the PV panel cool in $3 \mathrm{~s}$ and the frequency of $0.1 \mathrm{~Hz}$ leads the PV panel to heat up again, the optimum

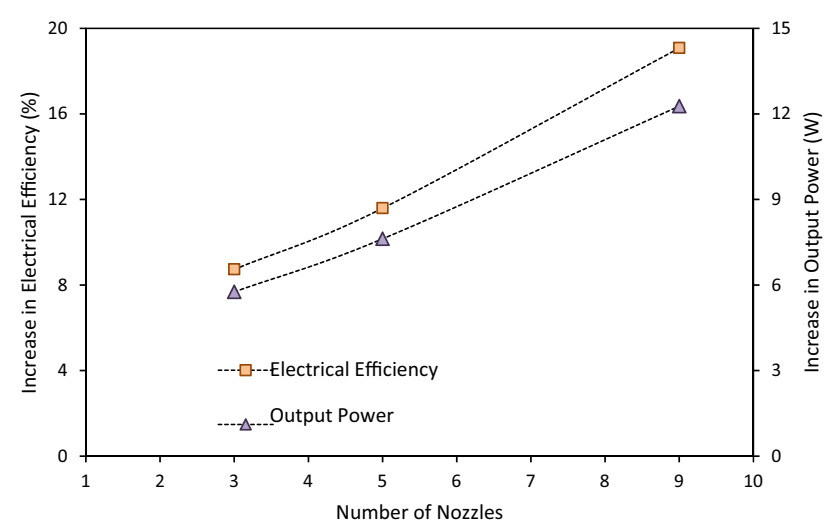

Fig. 17 Increase in electrical efficiency and output power of PV panel in different number of nozzles period frequency is $0.2 \mathrm{~Hz}$ due to its efficient water spraying period which is $5 \mathrm{~s}$ On- $5 \mathrm{~s}$ Off. By using on-off water spraying, the water consumption reduced to half.

The results show that On-Off cooling significantly reduced the water consumption for $50 \%$, but the electrical efficiency and output power are reduced about $9 \%$ compared to steady-state water spray cooling.

As can be seen in Fig. 18 the maximum increase of $16.84 \%$ in electrical efficiency was occurred for a frequency of $0.2 \mathrm{~Hz}$ compared to non-cooled PV panel. For other frequencies of $0.1 \mathrm{~Hz}$ and $0.33 \mathrm{~Hz}$ the increases in electrical efficiency were $14.46 \%$ and $16.31 \%$ respectively compared to non-cooled PV panel.

Figure 19 shows the effect of different frequencies on increased output power comparing to non-cooling mode. According to this figure, the maximum increase in output power occurs in frequency of 0.2 which is $11.4 \mathrm{~W}$. The following frequencies, 0.33 and $0.1 \mathrm{~Hz}$, cause 9.6 and $8.2 \mathrm{~W}$ increase in output power compared to non-cooled PV panel respectively.

Since water spray cooling system has a great effect on increasing the electrical efficiency and decreasing the photovoltaic panel temperature, it will mostly be applied in hot and dry regions. But water crisis is always a crucial issue in these regions, thus using pulsating on-off water spray can be a useful solution to reduce water consumption to half. Also, it is not essential to perform water spray cooling all day long. It can be utilized only in the peak hour of irradiation or in the high temperatures during the day.

\section{Conclusions}

In this paper we have presented a novel approach to enhance the PV panels performance. Following the direct relation between the PV panel temperature and its performance, water spray cooling method is selected

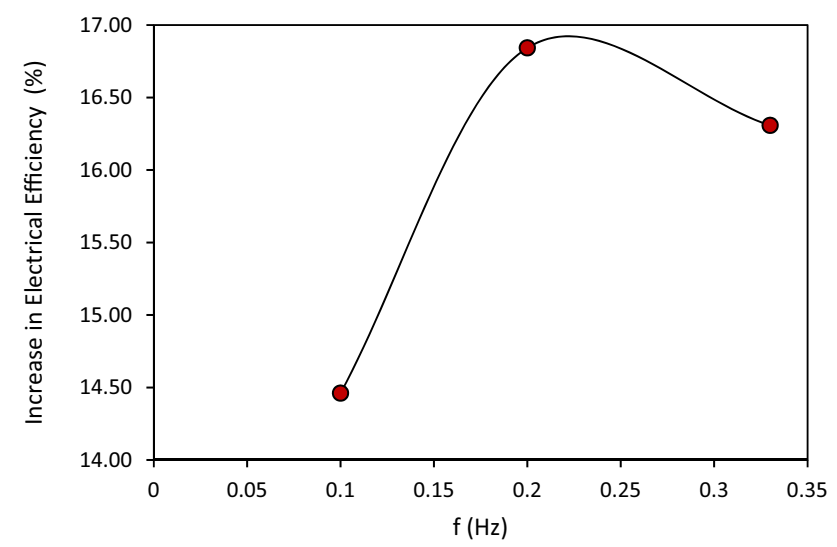

Fig. 18 Effect of spray frequency on electrical efficiency 


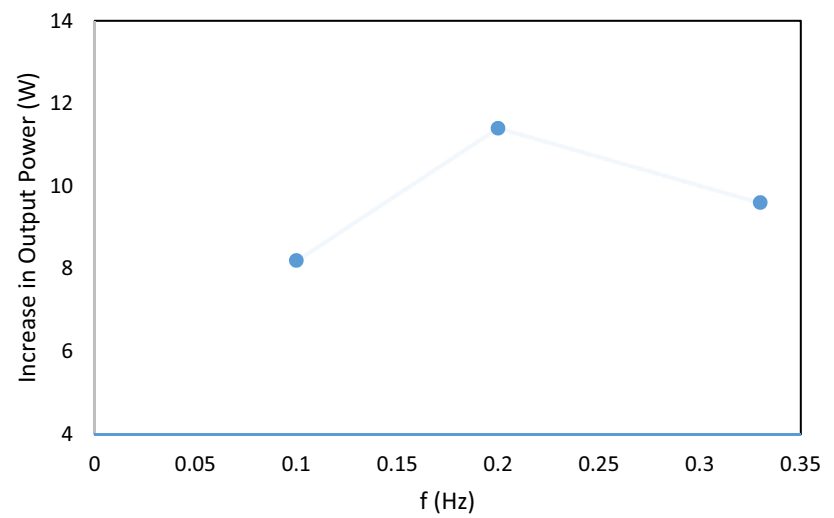

Fig. 19 Effect of spray frequency on output power

to be discussed. A specific experimental setup has been made to investigate the effects of different parameters on PV panel performance. The effects of water spray angle, water flow rate, and nozzles to PV panel distance on PV panel performance were assessed. The experiments illustrate that water spray cooling enhances PV panel performance.

The results of this study support the idea that by reducing the spray angle of the cooling water, the electrical efficiency and output power increase. The lowest angle (15 degree) results the best performance compared to other angles. Also, reducing the nozzles to PV panel distance increase the electrical efficiency and output power. The findings show that the shortest distance reaches the optimum increase. The water flow rate is also proportional to electrical efficiency of PV panel. The experimental results indicate that by reducing the flow rate from 81 to $21 \mathrm{l} / \mathrm{h}$, water consumption is reduced by $45 \%$.

Using the On-Off cooling system significantly reduced the water consumption but the electrical efficiency and output power are reduced about $9 \%$ compared to steady water spraying mode. Due to the surface evaporation and the intensity of the radiation, increasing the water spraying frequency can increase or decrease the electrical efficiency as shown in Fig. 18 but frequency of $0.2 \mathrm{~Hz}$ results the best in this study.

The maximum increase in PV panel electrical efficiency is $25.86 \%$ compared to non-cooled mode, and it occurred at steady water spray cooling with $\mathrm{H} / \mathrm{L}=0.83$ and the spray angle $=15^{\circ}$ which they are the lowest nozzles to PV panel distance and spray angle respectively.

It will be important that future research provides the economic approach of this water spraying system. Further studies should investigate a hybrid system using water spray cooling system in companion with other cooling systems such as: heat sinks, fins cooling, and heat exchangers.

\section{Compliance with ethical standards}

Conflict of interest The authors have no conflicts of interest to declare that are relevant to the content of this article.

Open Access This article is licensed under a Creative Commons Attribution 4.0 International License, which permits use, sharing, adaptation, distribution and reproduction in any medium or format, as long as you give appropriate credit to the original author(s) and the source, provide a link to the Creative Commons licence, and indicate if changes were made. The images or other third party material in this article are included in the article's Creative Commons licence, unless indicated otherwise in a credit line to the material. If material is not included in the article's Creative Commons licence and your intended use is not permitted by statutory regulation or exceeds the permitted use, you will need to obtain permission directly from the copyright holder. To view a copy of this licence, visit http://creativecommons .org/licenses/by/4.0/.

\section{References}

1. Teo HG, Lee PS, Hawlader MNA (2012) An active cooling system for photovoltaic modules. Appl Energy 90:309-315. https://doi. org/10.1016/j.apenergy.2011.01.017

2. Dubey S, Sarvaiya JN, Seshadri B (2013) Temperature dependent Photovoltaic (PV) efficiency and its effect on PV production in the world-a review. Energy Procedia 33:311-321. https://doi. org/10.1016/j.egypro.2013.05.072

3. Abdolzadeh M, Ameri M (2009) Improving the effectiveness of a photovoltaic water pumping system by spraying water over the front of photovoltaic cells. Renew Energy. https://doi. org/10.1016/j.renene.2008.03.024

4. Zhu L, Raman A, Wang KX et al (2014) Radiative cooling of solar cells. Optica 1:32-38. https://doi.org/10.1364/OPTICA.1.000032

5. Neyer A, Drabiniok E (2014) Bionic micro porous evaporation foil for photovoltaic cell. Microelectr Eng 119:65-69. https://doi. org/10.1016/j.mee.2014.02.013

6. Chandrasekar M, Suresh S, Senthilkumar T, Ganesh karthikeyan M (2013) Passive cooling of standalone flat PV module with cotton wick structures. Energy Convers Manage 71:43-50. https:// doi.org/10.1016/j.enconman.2013.03.012

7. Nada SA, El-Nagar DH, Hussein HMS (2018) Improving the thermal regulation and efficiency enhancement of PCM-Integrated PV modules using nano particles. Energy Convers Manage 166:735-743. https://doi.org/10.1016/j.enconman.2018.04.035

8. Popovici CG, Hudișteanu SV, Mateescu TD, Cherecheș N-C (2016) Efficiency improvement of photovoltaic panels by using air cooled heat sinks. Energy Procedia 85:425-432. https://doi. org/10.1016/j.egypro.2015.12.223

9. Yun GY, McEvoy M, Steemers K (2007) Design and overall energy performance of a ventilated photovoltaic facade. Sol Energy 81:383-394. https://doi.org/10.1016/j.solener.2006.06.016

10. Du JD, Darkwa J, Kokogiannakis G (2013) Thermal management systems for Photovoltaics (PV) installations: a critical review. Sol Energy 97:238-254. https://doi.org/10.1016/j.solen er.2013.08.018

11. Hasan A, McCormack SJ, Huang MJ, Norton B (2014) Energy and cost saving of a photovoltaic-phase change materials (PV$\mathrm{PCM}$ ) system through temperature regulation and performance 
enhancement of photovoltaics. Energies 7:1318-1331. https:// doi.org/10.3390/en7031318

12. Hasanuzzaman $M$, Malek ABMA, Islam MM, Pandey AK, Rahim NA (2016) Global advancement of cooling technologies for PV systems: A review. Sol Energy 137:25-45. https://doi. org/10.1016/j.solener.2016.07.010

13. Krauter S (2004) Increased electrical yield via water flow over the front of photovoltaic panels. Sol Energy Mater Sol Cells 82:131-137. https://doi.org/10.1016/j.solmat.2004.01.011

14. Alami AH (2014) Effects of evaporative cooling on efficiency of photovoltaic modules. Energy Convers Manage 77:668-679. https://doi.org/10.1016/j.rinp.2018.10.016

15. Nizetic S, Coko D, Yadav A, Grubišic-Cabo F (2016) Water spray cooling technique applied on a photovoltaic panel: The performance response. Energy Convers Manage 108:287-296. https ://doi.org/10.1016/j.enconman.2015.10.079

16. Moharrama KA, Abd-Elhady MS, Kandila HA, El-Sherif $\mathrm{H}$ (2013) Enhancing the performance of photovoltaic panels by water cooling. Ain Shams Eng J 4(4):869-877. https://doi. org/10.1016/j.asej.2013.03.005

17. Du B, Hu E, Kolhe M (2012) Performance analysis of water cooled concentrated photovoltaic (CPV) system. Renew Sustain Energy Rev 16(9):6732-6736. https://doi.org/10.1016/j.rser.2012.09.007

18. Fudholi A, Sopian K, Yazdi MH, Ruslan MH, Ibrahim A, Kazem HA (2014) Performance analysis of photovoltaic thermal (PVT) water collectors. Energy Convers Manage 78:641-651. https:// doi.org/10.1016/j.enconman.2013.11.017

19. Wu S-Y, Chen C, Xiao L (2018) Heat transfer characteristics and performance evaluation of water-cooled PV/T system with cooling channel above PV panel. Renew Energy 125:936-946. https://doi.org/10.1016/j.renene.2018.03.023

20. Nasrin R, Rahim NA, Fayaz H, Hasanuzzaman M (2018) Water/ MWCNT nanofluid based cooling system of PVT: Experimental and numerical. Renew Energy 121:286-300. https://doi. org/10.1016/j.renene.2018.01.014

21. Harry Ku (1966) Notes on the Use of Propagation of Error Formulas. J Res Natl Bureau Stand C Eng Instrum 70C(4):263-273

22. Singh GK (2013) Solar power generation by PV technology: a review. Energy 53:1-13. https://doi.org/10.1016/j.energ y.2013.02.057

23. Schiro F, Benato A, Stoppato A, Destro N (2017) Improving photovoltaics efficiency by water cooling: modelling and experimental approach. Energy 137:798-810. https://doi. org/10.1016/j.energy.2017.04.164

24. Nianyong Z, Fujiang C, Yuchun C, Mengmeng C, Wang Yu (2017) Experimental investigation on the performance of a water spray cooling system. Appl Therm Eng 112:1117-1128. https://doi. org/10.1016/j.applthermaleng.2016.10.191

25. Hnizdil M, Chabicovsky M, Raudensky M (2014) Influence of the impact angle and pressure on the spray cooling of vertically moving hot steel surfaces. Materiali in Tehnologije/Mater Technol 49(3):333-336. https://doi.org/10.17222/mit.2013.239

Publisher's Note Springer Nature remains neutral with regard to jurisdictional claims in published maps and institutional affiliations. 